\title{
LIGNOCELLULOSIC COMPOSITES FROM BRAZILIAN GIANT BAMBOO (Guadua magna) PART 1: PROPERTIES OF RESIN BONDED PARTICLEBOARDS
}

\author{
Larissa M. Arruda ${ }^{1}$, Cláudio H. S. Del Menezzi ${ }^{2}$, Divino E. Teixeira ${ }^{3}$, Priscila C. De Araújo ${ }^{4}$
}

\begin{abstract}
This experiment evaluated the utilization of the recently identified Brazilian giant bamboo, Guadua magna (Londoño \& Filg.) to manufacture medium density particleboard. Four board types were tested: two of them exclusively with particles of bamboo and two in a mixture of bamboo with Pinus taeda wood particles. The target density of the panels was $0.65 \mathrm{~g} / \mathrm{cm}^{3}$ for all treatments. The particleboards were bonded using $8 \%$ content of urea-formaldehyde (UF) and phenol-formaldehyde (PF) resins, based on dry weight mat. Mechanical, physical and nondestructive properties of the panels were assessed. The particleboards produced with PF showed better dimensional stability than UF particleboards. The addition of wood particles improved the mechanical properties of $\mathrm{E}_{\mathrm{M}}, \mathrm{f}_{\mathrm{M}}$ and IB. The flexural properties of the panels $\left(\mathrm{E}_{\mathrm{M}}, \mathrm{f}_{\mathrm{M}}\right)$ could be modeled using either $\mathrm{E}_{\mathrm{Md}}$ or density and the models fitted presented high predictability $(>66 \%)$.
\end{abstract}

Keywords: particleboard, bamboo, Guadua magna, Pinus taeda, nondestructive testing.

\section{INTRODUCTION}

In Brazil the production of timber from planted forests for industrial use increased 2.1\% per year in the last 10 years, reaching 162.5 million $\mathrm{m}^{3}$ in 2009 (Associação Brasileira dos Produtores de Florestas Plantadas - ABRAF, 2010). For better utilization of this resource, the Brazilian panel industry is investing in the quality of the production line, updating technologies and modernizing industrial plants (Mattos et al. 2008).

The Brazilian production of reconstituted wood based panels was about 5.28 million $\mathrm{m}^{3}$ in 2009 (ABRAF, 2010): $47.1 \%$ of this volume comprised medium density particleboard (MDP), followed by medium density fiberboard (MDF) (45.3\%) and hardboard (7.6\%). This value does not comprise oriented strandboard (OSB), whose production in 2009 was around $350,000 \mathrm{~m}^{3}$. Other materials such as agribased residues have been investigated and used to produce reconstituted panels (Teixeira et al. 2009; Almeida et al. 2002; Okino et al. 1997). Various sources of agricultural lignocellulosic fibers, namely wheat straw, kenaf, bamboo, rice husk an rice straw, can be used to manufacture composites (Hiziroglu et al. 2008). In this context, bamboo can be considered an excellent alternative to replace wood in the particleboard industry. Calegari et al. (2007) reported the use of bamboo particles (Bambusa vulgaris) for particleboard manufacturing and concluded that the properties were similar to that of panels made with $100 \%$ of wood.

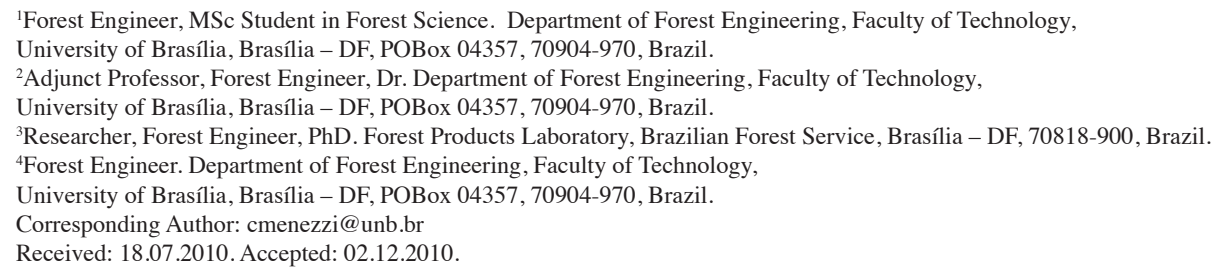


There are 34 bamboo genera and some 232 species in Brazil, a few not yet botanically identified. Seventy five percent of these species are considered endemic and $89 \%$ of all known genera and around $65 \%$ of all species in the New World are in Brazil (Filgueiras and Gonçalves 2004). Thus, there is a huge potential for developing products using bamboo as raw material in Brazil.

The species of bamboo used in this experiment was collected in the Brazilian state of Goiás (Midwestern region) and recently described by Filgueiras and Londoño (2006). The geographic distribution and habitat of G. magna appear to be quite distinct from those of G. angustifolia, which occurs in moist inter-Andean valleys of Northwestern region of South America. On the other hand, $G$. magna occurs in river banks along Gallery Forests in Central Brazil (Filgueiras and Londoño 2006). The typical G. magna bamboo has $12.6-23.4 \mathrm{~m}$ of height and $6-12 \mathrm{~cm}$ of diameter and is expected to have potential applications in civil engineering, housing, furniture, general farm uses, etc. Several local artists and artisans are looking for alternative uses for the culms of "taquaruçu". In rural localities of occurrence, it is traditionally used to build rustic homes, and other constructions, such as barns, fences, etc.

Blending wood or even other lignocellulosic fibers to manufacture particleboard is commonly reported in the literature. According to Vital et al. (1974) the characteristics of particleboards with a mixture of raw materials are similar to those produced with only one type of material and it depends exclusively on the density of the mixture. It is usual mixing wood of different densities (del Menezzi et al. 1996; Hillig et al. 2002; Naumann et al. 2008; Vital et al. 1974) or blending wood with bamboo fibers (Almeida et al. 2008; Calegari et al. 2007; Hiziroglu et al. 2005). In this context, this research was designed to evaluate the technical feasibility of blending particles of bamboo (G. magna) and Pinus taeda for producing particleboard bonded with synthetic resins (UF and PF) as well as to assess the properties of the panels.

\section{MATERIALS AND METHODS}

\section{Particles preparation}

The culms of bamboo were obtained in the state of Goiás, Midwestern region, and the logs of Pinus taeda 21 years old were collected in Arapoti, Southern region. The materials were stored in an environmentally controlled room at $(22 \pm 2)^{\circ} \mathrm{C}$ and $(60 \pm 2) \%$ relative humidity. The culms were immersed in water for one week to diminish the starch, sugar and soluble materials content. This procedure was necessary to make cutting easier and to reduce biodegradation. The culms were then cut into slices $(20 \mathrm{~cm}$ long) and processed in a rotary disk flaker. The wood was cut into blocks with dimensions of $19 \mathrm{~cm}$ by $20 \mathrm{~cm}$ by $3.5 \mathrm{~cm}$ along the grain and chipped into flakes. Afterwards, the flakes from the bamboo and the wood were separately reduced to particles in a hammer mill through a mesh wire of $5 \mathrm{~mm}$ opening.

The particles were screened through three sieves, in the following order: a. $3.0 \mathrm{~mm}$; b. $1.5 \mathrm{~mm}$; c. $1.0 \mathrm{~mm}$. The particles that passed the $3.0 \mathrm{~mm}$ sieve and were retained in the sieves of $1.0 \mathrm{~mm}$ and 1.5 $\mathrm{mm}$ were used for particleboard manufacturing. After screening, the wood and bamboo particles were dried to $5 \%$ moisture content at $70^{\circ} \mathrm{C}$. Only particles of bamboo were weighed to verify the processing yield. However, the particle dimensions were determined for both species.

\section{Board manufacturing and testing}

The pre-weighed furnish $(\approx 760 \mathrm{~g})$ was placed into a rotary blender and mixed with urea-formaldehyde (labeled as BB/UF) and phenol-formaldehyde (labeled as BB/PF) resins with $61 \%$ and $46.5 \%$ of solids content, respectively. Based on the solids content of UF, $2 \%$ of ammonium chloride was used as hardener. The amount of either resin, in each board manufactured, was $8 \%$ based on the dry weight of particles. The homogenized mixture was hand-formed into mats of $300 \mathrm{~mm} \times 300 \mathrm{~mm}$ and hot pressed at $170^{\circ} \mathrm{C}$ for 10 minutes using a nominal pressure of $4.0 \mathrm{~N} / \mathrm{mm}^{2}$. Three replicates (panels) were produced for each board type. After manufacturing, the boards were conditioned at $(22 \pm 2)^{\circ} \mathrm{C}$ and $(60 \pm 2) \%$ relative 
humidity. The target board density was $0.65 \mathrm{~g} / \mathrm{cm}^{3}$ and the target board thickness set to $13.0 \mathrm{~mm}$. The boards were manufactured according to four treatments outlined in Table 1.

Table 1. Treatments of the particleboards made with $100 \%$ bamboo and blends of bamboo with wood particles.

\begin{tabular}{lcccc}
\hline Treatment & Adhesive & $\begin{array}{c}\text { Target } \\
\text { compression } \\
\text { ratio }\end{array}$ & Proportion of particles & $\begin{array}{c}\text { Target density } \\
\left(\mathbf{g} / \mathbf{c m}^{3}\right)\end{array}$ \\
\hline BB/UF & UF & 1.41 & $100 \%$ bamboo, 0\% wood & 0.65 \\
BB/PF & PF & 1.41 & $100 \%$ bamboo, 0\% wood & 0.65 \\
BP25/PF & PF & 1.44 & $75 \%$ bamboo, 25\% wood & 0.65 \\
BP50/PF & PF & 1.47 & $50 \%$ bamboo, $50 \%$ wood & 0.65 \\
\hline
\end{tabular}

For panels with mixture of bamboo and $P$. taeda particles, the compression ratio was based on the density of the mixture and calculated according to Del Menezzi et al. (1996). Each board was cut in specimen according to NBR 14810-3 standard (Associação Brasileira de Normas Técnicas - ABNT 2002). The following properties were evaluated: static bending (modulus of rupture, $\mathrm{f}_{\mathrm{M}}$ and modulus of elasticity, $\mathrm{E}_{\mathrm{M}}$ ), internal bonding (IB), direct surface screw withdrawal (SW), board density (D), thickness swelling (TS), water absorption (WA), and moisture content (MC). The values of the properties were compared with those presented as minimum requirements according to ANSI A208.1 standard (American National Standard - ANSI 1999).

Furthermore, the samples were nondestructively tested (NDT) using a Stress Wave Timer (SWT) equipment. This technique takes a wave produced by an impact in one side of the material, which travels along the length of the sample to reach an accelerometer at the other end. The time to reach this distance is displayed in the SWT device and used to calculate the stress wave velocity (wv). Wave velocity (Wv) in addition to the material density and acceleration due to gravity were used to determinate the dynamic modulus of elasticity (EMd) according to Souza et al. (2010) (equations 1 and 2).

$$
\begin{gathered}
v_{o}=\frac{L}{t \times 10^{-6}} \\
E_{M d}=\frac{v_{o}^{2} \times D}{g} \times 10^{-5}
\end{gathered}
$$

Where:

$\mathrm{v}_{\mathrm{o}}$ : stress wave velocity, $\mathrm{m} / \mathrm{s} ; \mathrm{E}_{\mathrm{Md}}$ : dynamic modulus of elasticity, $\mathrm{N} / \mathrm{mm}^{2} ; \mathrm{D}$ : density, $\mathrm{kg} / \mathrm{m}^{3} ; \mathrm{L}$ : length of the beam, $\mathrm{m}$; t: wave transit time, $\mu \mathrm{s} ; \mathrm{g}$ : acceleration of gravity, $9.8 \mathrm{~m} / \mathrm{s}^{2}$; 
Initially, the results for each treatment were separately submitted to an overall analysis of variance (ANOVA) at 5\% significance level in order to test between-board effects. Afterwards, between-treatment effects were analyzed by running again an ANOVA at 5\% significance level. In that later analysis the number of replicates was 15 , the quantity of specimen cut per property for each treatment. To test the influence of the addition of wood, an analysis of co-variance (ANCOVA) was run using the board density as covariate. The Tukey test was used to separate the means among treatments for the properties where the difference was significant. Fisher LSD test (Least Significant Difference) evaluated the means by pairwise comparisons, based on estimated marginal means. Two regression models (linear and non-linear) were tested to evaluate NDT variables to predict flexural properties $\left(\mathrm{E}_{\mathrm{M}}\right.$ and $\mathrm{f}_{\mathrm{M}}$ ) from $\mathrm{E}_{\mathrm{Md}}$, density and wv.

\section{RESULTS AND DISCUSSION}

\section{Processing yield of bamboo and dimension of the particles}

During the processing of bamboo in the flaker there was a considerable formation of fines, which is not appropriate for the manufacture of particleboards. After processing of bamboo culms, $74 \mathrm{~kg}$ of bamboo flakes were produced, $6 \mathrm{~kg}$ of which were lost during screening, as air-borne dust material. The bamboo particles were typically longer, thinner and narrower than the wood ones. As a result, their slenderness ratio was higher than that of the wood particles (Table 2).

Table 2. Dimensions of bamboo and wood particles ${ }^{\mathrm{a}, \mathrm{b}}$.

\begin{tabular}{ccc}
\hline Length $(\mathbf{m m})$ & $9.19(39.28)$ & $12.93(37.58)$ \\
Thickness $(\mathbf{m m})$ & $0.56(30.35)$ & $0.4(35.0)$ \\
Slenderness ratio & 16.31 & 32.29 \\
\hline
\end{tabular}

a. Coefficient of variation (\%) in parentheses. ${ }^{\text {b. }}$ The values shown are means from 100 samples.

Moslemi (1974) commented that the best slenderness ratio should range from 120 to 200. Particles within such ratios are often thin and long, possessing good bending properties along with good board stability. Therefore, in this work the dimensions of both wood and bamboo particles were not within the recommended.

\section{Physical properties}

The observed density was close to the target set for all the treatments (Table 4). The treatment with addition of $50 \%$ wood produced panels with the highest density $\left(0.69 \mathrm{~g} / \mathrm{cm}^{3}\right)$, as expected. ANOVA tests suggested that the difference between densities in $\mathrm{BB} / \mathrm{UF}$ and $\mathrm{BB} / \mathrm{PF}$ was not significant. Boards made with $100 \%$ bamboo particles and bonded with UF (BB/UF) resin showed higher TS than those made with PF. It resulted in PF boards with better dimensional stability compared to UF bonded boards. However, water absorption in boards with PF was higher in the two hours soaking, but after 24 hours the difference was not significant. The MC of BB/PF (10.15\%) was higher than BB/UF (9.02\%) showing that the panels with PF resin adsorbed more moisture after manufacturing (Table 3). 
Table 3. Values of physical, mechanical and nondestructive properties obtained from boards made with $100 \%$ bamboo particles a (Number of specimen=15 per treatment).

\begin{tabular}{|c|c|c|c|c|c|c|c|c|c|}
\hline Treat. & Density & $\mathbf{T S}^{\mathbf{b}}$ & $\mathbf{W A}^{\mathbf{b}}$ & MC & $\mathbf{E}_{\mathbf{M}}$ & $\mathbf{f}_{\mathbf{M}}$ & IB & $\mathbf{E}_{\mathbf{M d}}$ & SW \\
\hline & $\mathrm{g} / \mathrm{cm}^{3}$ & & $\%$ & & \multicolumn{4}{|c|}{$\mathrm{N} / \mathrm{mm}^{2}$} & $\mathrm{~N}$ \\
\hline \multirow{2}{*}{ BB/UF } & $0.64^{\mathrm{NS}}$ & $21.86^{*}$ & $77.19^{\mathrm{NS}}$ & $9.02 *$ & $1819.34^{\mathrm{NS}}$ & $13.44^{\mathrm{NS}}$ & $0.32 *$ & $2471.91^{\mathrm{NS}}$ & $623.77^{\mathrm{NS}}$ \\
\hline & $(4.68)$ & $(24.65)$ & $(12.08)$ & $(0.83)$ & $(12.98)$ & $(15.62)$ & (28.46) & $(8.20)$ & (17.15) \\
\hline \multirow{2}{*}{ BB/PF } & $0.65^{\mathrm{NS}}$ & $18.20^{*}$ & $81.77^{\mathrm{NS}}$ & $10.15^{*}$ & $1722.70^{\mathrm{NS}}$ & $13.60^{\mathrm{NS}}$ & $0.26^{*}$ & $2481.18^{\mathrm{NS}}$ & $654.57^{\mathrm{NS}}$ \\
\hline & $(4.62)$ & (6.86) & (10.56) & $(0.76)$ & (8.73) & (15.25) & (26.07) & (11.88) & (20.83) \\
\hline
\end{tabular}

a. Coefficient of variation (\%) in parenthesis. ${ }^{\text {b. }}$ After 24 hours. $*$ The mean difference is significant at $5 \%$ level. NS: not significant at 5\% level; TS = thickness swelling; $\mathrm{WA}=$ water absorption;

$\mathrm{MC}=$ moisture content $\mathrm{E}_{\mathrm{M}}=$ modulus of elasticity; $\mathrm{f}_{\mathrm{M}}=$ modulus of rupture; $\mathrm{IB}$ = internal bonding; $\mathrm{E}_{\mathrm{Md}}=$ dynamic modulus of elasticity; $\mathrm{SW}=$ screw withdrawal.

Evaluating the addition of wood in treatments BB/PF, BP25/PF and BP50/PF, the ANOVA presented evidence of difference among density means and the Tukey test divided this means in groups (Table 4). Thus, assuming density as a covariate (grand mean equals $0.67 \mathrm{~g} / \mathrm{cm}^{3}$ ), the values were estimated for these treatments. Based in this density, means were estimated for all physical and mechanical properties, except MC (Table 5). Comparing pairs of values between treatments, the LSD test identified no significance to TS, WA and MC in treatments of panels with addition of wood. These results mean that the addition of wood did not affect water-related properties.

Table 4. Result of Tukey test for observed densities in treatments with PF resin a.

\begin{tabular}{lccc}
\hline & & \multicolumn{2}{c}{${\text { Density }\left(\mathbf{g} / \mathbf{c m}^{3}\right)}^{\text {Treatment }}$} \\
& N. Specimen & \multicolumn{2}{c}{2} \\
\cline { 2 - 3 } BB/PF & 15 & 0.65 & 0.67 \\
BP25/PF & 15 & & 0.69 \\
BP50/PF & 15 & & 1 \\
\hline
\end{tabular}

a. Based on observed means. Means in same group were not significant at 5\% significance level.

b. number of specimens taken to calculate mean density.

\section{Mechanical properties}

Comparing boards made with $100 \%$ bamboo particles and manufactured with UF and PF resins, the ANOVA test showed no difference between EM and fM. However, it was expected that the boards produced with PF presented better mechanical properties since this resin generally produces stronger bond links than melamine and urea based resins (Iwakiri et al. 2005).

Comparing the estimated means for $\mathrm{E}_{\mathrm{M}}$ and $\mathrm{f}_{\mathrm{M}}$ in treatments BB/PF, BP25/PF and BP50/PF, the addition of $25 \%$ of wood particles did not have an effect on the $\mathrm{E}_{\mathrm{M}}$, but $50 \%$ of wood caused an improvement of $8.82 \%$ in $\mathrm{E}_{\mathrm{M}}$. Regarding $\mathrm{f}_{\mathrm{M}}$, the Fisher LSD test identified significance difference among these treatments showing that $\mathrm{f}_{\mathrm{M}}$ increases with increase in the proportion of wood $\left(15.03 \mathrm{~N} / \mathrm{mm}^{2}, 16.65\right.$ $\mathrm{N} / \mathrm{mm}^{2}$ and $17.68 \mathrm{~N} / \mathrm{mm}^{2}$, respectively) (Table 5). 
Table 5. Estimated values of physical and mechanical properties of treatments made from mixture of bamboo and wood particles (Pinus taeda) a,b.

\begin{tabular}{|c|c|c|c|c|c|c|c|c|}
\hline Treat. & $\mathbf{T S}^{\mathbf{c}}$ & $\mathbf{W A}^{\mathbf{c}}$ & $\mathbf{M C}^{\mathrm{d}}$ & $\mathbf{E}_{\mathbf{M}}$ & $\mathbf{f}_{\mathbf{M}}$ & IB & $\mathbf{E}_{\mathbf{M d}}$ & SW \\
\hline & & $\%$ & & \multicolumn{4}{|c|}{$\mathrm{N} / \mathrm{mm}^{2}$} & $\mathrm{~N}$ \\
\hline \multirow{2}{*}{ BB/PF } & $18.61 \mathrm{a}$ & $77.47 \mathrm{a}$ & $10.15^{\mathrm{NS}}$ & $1845.63 \mathrm{a}$ & $15.03 \mathrm{a}$ & $0.28 \mathrm{a}$ & $2635.15 a$ & $668.19 a$ \\
\hline & $(6.66)$ & (2.26) & $(0.78)$ & (1.77) & $(2.55)$ & (13.12) & (1.44) & (4.41) \\
\hline \multirow{2}{*}{ BP25/PF } & $21.17 \mathrm{a}$ & $79.06 \mathrm{a}$ & $10.02^{\mathrm{NS}}$ & $1888.15 a$ & $16.65 \mathrm{~b}$ & $0.47 b$ & $2707.15 a$ & $711.48 \mathrm{a}$ \\
\hline & $(5.23)$ & $(1.98)$ & & & & $(7.43)$ & & \\
\hline \multirow{2}{*}{ BP50/PF } & $20.44 a$ & $78.12 \mathrm{a}$ & $10.23^{\mathrm{NS}}$ & $2008.58 b$ & $17.68 \mathrm{c}$ & $0.40 \mathrm{~b}$ & $2608.61 a$ & $665.55 a$ \\
\hline & $(5.85)$ & $(2.16)$ & $(0.69)$ & (1.57) & $(2.09)$ & $(9.01)$ & & (4.59) \\
\hline
\end{tabular}

a. Coefficient of variation (\%) in parenthesis. ${ }^{\text {b. }}$ Based on estimated marginal means (density $\left.=0.667\right)$. ${ }^{\text {c. }}$ After 24 hours. ${ }^{\text {d. }}$ Means not estimated in analysis of covariance. Different letters indicate that the mean difference is significant at 5\% significance level on Fisher LSD test. TS = thickness swelling; WA = water absorption; MC = moisture content; $\mathrm{E}_{\mathrm{M}}=$ modulus of elasticity; $\mathrm{f}_{\mathrm{M}}=$ modulus of rupture; $\mathrm{IB}=$ internal bonding; $\mathrm{E}_{\mathrm{Md}}=\mathrm{dynamic}$ modulus of elasticity; $\mathrm{SW}=$ screw withdrawal.

The addition of $50 \%$ of wood in the boards of bamboo increased $f_{M}$ in $17.63 \%$. According to $E_{M}$ and $\mathrm{f}_{\mathrm{M}}$ values, the boards (bamboo and bamboo + wood) may be classified as M-1 (for commercial use) based on the ANSI A208.1 standard. The flexural properties values obtained in this study are consistent with values reported in other papers. Papadopoulos et al. (2004) studied the technical feasibility of using Bambusa vulgaris for particleboard manufacture. For a denser particleboard $\left(0.754 \mathrm{~g} / \mathrm{cm}^{3}\right)$ manufactured with higher UF resin content $(10 \%)$ they found $\mathrm{f}_{\mathrm{M}}$ values around $13.9 \mathrm{~N} / \mathrm{mm}^{-2}$. However, for this same bamboo species, Chew and Sudim (1992) found $16.9 \mathrm{~N} / \mathrm{mm}^{2}$ for $8 \%$-UF-resin bonded particleboard. Hiziroglu et al. (2005) found in boards made with a blend of $50 \% / 50 \%$ of wood particles (Eucalyptus camaldulensis) and bamboo (Dendrocalamus asper) higher values for $\mathrm{E}_{\mathrm{M}}\left(2689.0 \mathrm{~N} / \mathrm{mm}^{2}\right)$ and $\mathrm{f}_{\mathrm{M}}(25.5$ $\mathrm{N} / \mathrm{mm}^{2}$ ) than boards manufactured in this study. The authors observed that $50 \%$ of wood with bamboo increased the $\mathrm{E}_{\mathrm{M}}$ in $10.9 \%$ and $\mathrm{f}_{\mathrm{M}}$ in $11.87 \%$. Lee et al. (2006), mixing bamboo (50\% Phyllostachis pubescens) with bagasse $(50 \%)$, produced a high density particleboard $\left(1.09 \mathrm{~g} / \mathrm{cm}^{3}\right)$ that showed $\mathrm{f}_{\mathrm{M}}$ value around $33 \mathrm{~N} / \mathrm{mm}^{2}$ and $\mathrm{E}_{\mathrm{M}}$ value around $3600 \mathrm{~N} / \mathrm{mm}^{2}$.

Among treatments manufactured with $100 \%$ bamboo, panels made with UF resin showed the highest value for IB $\left(0.32 \mathrm{~N} / \mathrm{mm}^{2}\right)$. PF boards obtained the lowest value $\left(0.26 \mathrm{~N} / \mathrm{mm}^{2}\right)$ in the IB test, although they had low TS. This result was not expected because lower TS values represent higher cohesion between the particles, providing better dimensional stability and generally presenting higher IB values. These IB values were unsatisfactory according to the ANSI A208.1 standard (ANSI 1999), that requires a minimum value of $0.40 \mathrm{~N} / \mathrm{mm}^{2}$ for IB in particleboard.

The addition of wood increased the IB value by $67.8 \%$. This can be related to the structure of wood particles that provides a uniform glue-line compared with bamboo particles, since they presented smoother and flatter surface than bamboo particles. Boards made exclusively with bamboo particles $(\mathrm{BB} / \mathrm{PF})$ presented the lowest estimated value for IB $\left(0.28 \mathrm{~N} / \mathrm{mm}^{2}\right)$ (Table 5). Comparing treatments with addition of wood, the difference between estimated means of IB in treatments BP25/PF and BP50/ PF was not significant. Estimated means of IB in these treatments were satisfactory according to A208.1 (ANSI 1999).

All the boards in this study showed low SW values. Boards made with $100 \%$ bamboo particles and bonded with UF resin resulted in the lower SW value $(623.8 \mathrm{~N})$ and boards with $25 \%$ of wood particles 
the higher $(711.5 \mathrm{~N})$ as seen in Tables 3 and 5. Thus, none of the boards satisfied SW requirements based on the ANSI A208.1 standard for particleboard graded for commercial use (ANSI, 1999). Kalemwork et al. (2005) studied an Ethiopian bamboo (Yushana alpina) for particleboard manufacture. The results obtained for SW ranged from $773 \mathrm{~N}$ to $878 \mathrm{~N}$ for a $10 \%$-UF bonded particleboard.

\section{Nondestructive testing}

In the industrial manufacture of wood-based composite materials, some samples are selected to destructive testing for quality control. However, there is virtually no assurance that the next board, or even the next 100 boards, will have the same properties. The quality can further be assessed using NDT methods to quickly and accurately evaluate the wood-based panels' properties (Ross and Pellerin 1988). Targa et al. (2005) suggest that due to viscoelastic behavior, the EM values obtained in the static tests are lower than those from the dynamic testing (EMd). Usually, dynamic properties overestimate static properties and this is drawback of the nondestructive evaluation. In all the treatments of this study, EMd values overestimated the EM up to 44\%. The stress wave velocities of the boards were: $1943 \mathrm{~m} / \mathrm{s}$ (BB/ $\mathrm{UF}), 1937 \mathrm{~m} / \mathrm{s}(\mathrm{BB} / \mathrm{PF}), 1996 \mathrm{~m} / \mathrm{s}(\mathrm{BP} 25 / \mathrm{PF})$ and $1975 \mathrm{~m} / \mathrm{s}$ (BP50/PF).

According to Souza et al. (2010) several studies have suggested that an increase in material continuity, i.e. a decrease in empty spaces, increases stress wave velocity of the board. In this context the particle geometry plays an important role. In fact, Han et al. (2006) observed the following stress wave velocities according to the kind of the board evaluated: $\approx 1870 \mathrm{~m} / \mathrm{s}$ (particleboard), $\approx 2770 \mathrm{~m} / \mathrm{s}(\mathrm{OSB})$ and $\approx 4300$ $\mathrm{m} / \mathrm{s}$ (plywood). Del Menezzi et al. (2007) found a stress wave velocity around $2850 \mathrm{~m} / \mathrm{s}$ for thermally treated OSB. Recently, Souza et al. (2010) evaluated LVL boards made from Pinus oocarpa and P. kesyia nondestructively and the stress wave velocity ranged from $4686 \mathrm{~m} / \mathrm{s}$ to $4946 \mathrm{~m} / \mathrm{s}$ depending on the position of the panel assessed.

In wood-based composites, there are many voids and regions with different properties. Therefore, during NDT, a reduction in stress wave velocity can take place and consequently lead to a low EMd compared with EMd in wood. In this study, the lower value of EMd was $2471.91 \mathrm{~N} / \mathrm{mm}^{2}$ and the maximum was $2707.15 \mathrm{~N} / \mathrm{mm}^{2}$. When just stress wave velocity (wv) was used as a independent variable to predict $\mathrm{f}_{\mathrm{M}}$ and $\mathrm{E}_{\mathrm{M}}$, both linear and non-linear models presented low $\mathrm{R}^{2}$ values. Despite this finding, Souza et al. (2010) found that stress wave velocity only might have potential to predict $\mathrm{E}_{\mathrm{M}}$ of LVL boards since a fitted model using this variable gave a coefficient of determination $\left(\mathrm{R}^{2}\right)$ of ca. 0.5 . Otherwise, $\mathrm{E}_{\mathrm{Md}}$ showed good correlation with $\mathrm{E}_{\mathrm{M}}$ and $\mathrm{f}_{\mathrm{M}}$, especially in BB/UF and BP50/PF boards, and the maximum value of $\mathrm{R}^{2}$ in these regressions was $83 \%$ (Table 6). According to Teixeira and Moslemi (2001), in studies with wood-based composites this $\mathrm{R}^{2}$ is acceptable and highly significant. Additionally, the results obtained in this present work are similar to those observed by other authors for wood-based panels. Ferraz et al. (2009) employed the same nondestructive method to predict flexural properties of laminated strand lumber (LSL) and oriented strand lumber (OSL) made from Chrysophyllum sp., a Brazilian tropical hardwood. Models with $\mathrm{R}^{2}$ ranging from 0.59 to 0.80 could be modeled to explain the variation of the flexural properties using $\mathrm{E}_{\mathrm{Md}}$ as a predictor.

Density also showed good correlation with mechanical properties, mainly with EM in the BB/UF treatment. Both models, linear and non-linear, had high $\mathrm{R}^{2}$ of 0.91 and 0.92 (Table 6). The good correlation of $\mathrm{E}_{\mathrm{Md}}$ and density with mechanical properties is important because it is possible to determinate these properties without destroying the material. 
Table 6. Linear and non-linear models fitted to predict flexural properties of the evaluated treatments.

\begin{tabular}{lcccccc}
\hline Treatment & \multicolumn{7}{c}{ Models } \\
\hline \multicolumn{1}{c}{ Linear } & $\mathrm{R}^{2}$ & SEE & Non-linear & $\mathrm{R}^{2}$ & SEE \\
\hline BB/UF & $\mathrm{E}_{\mathrm{M}}=-3067.611234+7629.612498 . \mathrm{D}$ & $91 \%$ & $3.93 \%$ & $\mathrm{E}_{\mathrm{M}}=6120.152783 . \mathrm{D}^{2.733964}$ & $92 \%$ & $3.71 \%$ \\
& $\mathrm{E}_{\mathrm{M}}=-796.099368+1.058058 . \mathrm{E}_{\mathrm{Md}}$ & $81 \%$ & $5.68 \%$ & $\mathrm{E}_{\mathrm{M}}=0.018840 . \mathrm{E}_{\mathrm{Md}}{ }^{1.468846}$ & $83 \%$ & $5.58 \%$ \\
\hline BB/PF & $\mathrm{f}_{\mathrm{M}}=-21.898924+54.997213 . \mathrm{D}$ & $66 \%$ & $8.89 \%$ & $\mathrm{f}_{\mathrm{M}}=44.848740 . \mathrm{D}^{2.738215}$ & $70 \%$ & $8.60 \%$ \\
\hline BP25/PF & $\mathrm{E}_{\mathrm{M}}=-3491.066144+8034.439946 . \mathrm{D}$ & $74 \%$ & $5.34 \%$ & $\mathrm{E}_{\mathrm{M}}=5947.315722 . \mathrm{D}^{2.866581}$ & $76 \%$ & $5.27 \%$ \\
\hline BP50/PF & $\mathrm{f}_{\mathrm{M}}=-8.547248+0.010017 . \mathrm{E}_{\mathrm{Md}}$ & $82 \%$ & $4.35 \%$ & $\mathrm{f}_{\mathrm{M}}=0.000219 . \mathrm{E}_{\mathrm{Md}}{ }^{1.435894}$ & $83 \%$ & $4.40 \%$ \\
\hline
\end{tabular}

$\mathrm{D}=$ specimen density $; \mathrm{E}_{\mathrm{M}}=$ modulus of elasticity; $\mathrm{f}_{\mathrm{M}}=$ modulus of rupture $\mathrm{E}_{\mathrm{Md}}=$ dynamic modulus of elasticity; $\mathrm{R}^{2}=$ coefficient of determination; $\mathrm{SEE}=$ standard error of estimative

\section{CONCLUSIONS}

The studied bamboo species contained too much parenchymatic cells and produced longer and thinner particles, which created a large amount of fines. Thus, the processing method must be improved. The type of resin apparently did not have an effect on bamboo boards made with Guadua magna, except for TS, $\mathrm{MC}$ and IB. The addition of wood particles in the bamboo boards improved the $\mathrm{E}_{\mathrm{M}}$ and $\mathrm{f}_{\mathrm{M}}$, while other properties were not affected. Evaluating $\mathrm{E}_{\mathrm{M}}$ and $\mathrm{f}_{\mathrm{M}}$, the particleboards were classified for commercial use (M-1) based in the ANSI A208.1 standard. The flexural properties of the panels $\left(E_{M}, f_{M}\right)$ could be modeled using either $\mathrm{E}_{\mathrm{Md}}$ or density and the models fitted presented medium-high predictability.

\section{ACKNOWLEDGMENTS}

To National Council for Scientific and Technological Development (CNPq) for providing Scholarship Grant to the first author, and to Schenectady Crios S/A for donating the resins used in this experiment.

\section{REFERENCES}

Almeida, R. R.; del Menezzi, C. H. S.; Teixeira, D. E. 2002. Utilization of the coconut shell of babaçu (Orbignya sp.) to produce cement-bonded particleboard. Bioresource Technology 85 : 159-163.

Almeida, A. L. A. de.; Valarelli, I. D. ; Lima, F. L. S. ; Battistelle, R. A. G. 2008. Avaliação das propriedades físicas das chapas homogêneas compostas de bambu e pinus utilizando resina poliuretana à base de mamona. In: $11^{\circ}$ Encontro Brasileiro em Madeiras e Estruturas de Madeira, Londrina.

American National Standard. 1999. (ANSI) . Particleboard. Designation: A208.1, Gaithersburg. Composite Panel Association.

Associação Brasileira dos Produtores de Florestas Plantadas. 2010. ABRAF Statistical Yearbook - Base Year 2009. Brasília, 127p.

Associação Brasileira de Normas Técnicas (ABNT). 2002. Chapas de Madeira Aglomerada. Designation: NBR 14.810, Rio de Janeiro, Brazil. 
Calegari, L.; Haselein, C. R.; Scavarelli, T. L.; Santini, E. J.; Stangerlin, D. M.; Gatto, D. A., Trevisan, R. 2007. Desempenho físico-mecânico de painéis fabricados com bambu (Bambusa vulgaris Schr.) em combinação com madeira. Cerne 13: 57-63.

Chew, L. T.; Sudin, R.; 1992. Bambusa vulgaris for urea and cement-bonded particleboard manufacture. Journal of Tropical Forest Science 4: 249-356.

del Menezzi, C. H. S.; Tomaselli, I, Souza, M. R. 2007. Avaliação não-destrutiva de painéis OSB modificados termicamente. Parte 1: efeito do tratamento térmico sobre a velocidade de propagação de ondas de tensão. Scientia Forestalis 76: 67-75.

del Menezzi, C. H. S., Souza, M. R., Gonçalez, J. C. 1996., Fabricação e avaliação tecnológica da chapa aglomerada de mistura de Eucalyptus urophylla T. S. Blake e Pinus oocarpa Schiede. Revista Árvore 20: 371-379.

Ferraz, J. M., Del Menezzi, C. H. S., Teixeira, D. E., Okino, E. Y. A., Souza, F., Bravim, A. G., 2009. Propriedades de painéis de partículas laminadas paralelas utilizados em substituição à madeira maciça. Cerne 19: 67-74.

Filgueiras, T. S.; Gonçalves, A. P. S. 2004. A Checklist of the basal grasses and bamboos in Brazil (Poaceae). Journal of American Bamboo Society 18: 7-18.

Filgueiras, T.S.; Londoño, X. A.; 2006. Giant new Guadua (Poaceae: Bambusoideae) from Central Brazil. In: Proceedings of $1^{\text {st }}$ National Seminar on Development of the Brazilian Bamboo Research Network, Brasília, Brazil, pp. 27 - 33.

Han, G.; Wu, Q.; Wang, X. 2006. Stress-wave velocity of wood based boards: effect of moisture, product type, and material direction. Forest Products Journal 56(1): 28-33.

Hillig, E.; Haselein, C. R.; Santini, E. J. 2002. Propriedades mecânicas de chapas aglomeradas estruturais fabricadas com madeiras de pinus, eucalipto e acácia-negra. Ciência Florestal 12 (1): 5970 .

Hiziroglu, S.; Jarusombuti, S.; Bauchongkol, P.; Fueangvivat, V. 2008. Overlaying properties of fiberboard manufactured from bamboo and rice straw. Industrial Crops \& Products 28: 107-111.

Hiziroglu, S.; Jarusombuti, S.; Fueangvivat, V.; Bauchongkol, P.; Soontonbura, W.; Darapak, T. 2005. Properties of bamboo - rice straw - eucalyptus composite panels. Forest Products Journal 55 (12): 221-225.

Iwakiri, S.; Caprara, A. C.; Saks, D. C. O.; Guisantes, F. P.; Franzoni, J. A.; Krambeck, L. B. P.; Rigatto, P. A. 2005. Produção de painéis de madeira aglomerada de alta densificação com diferentes tipos de resinas. Scientia Forestalis 68: 39-43.

Kalemwork, S.; Tahir, P. M.; Ding, W. E.; Ashaari, Z. 2005. Effects of particle size and orientation on properties of particleboard made from Ethiopian Highland bamboo (Yushana alpina). In Proceedings of Scientific Session 90, IUFRO XXII World Congress, Brisbane, p. 65-71.

Lee, S.; Shupe, T. F.; Hse, C. Y. 2006. Mechanical and physical properties of agro-based fiberboard. Holz als Roh- und Werkstoff 64: 74-79. 
Mattos, R. L. G.; Gonçalves, R. M.; Chagas, F. B. das. 2008. Painéis de madeira no Brasil: panorama e perspectivas. BNDES setorial, Rio de Janeiro 27: 121-156.

Moslemi, A. A.; 1974. Particleboard, $2^{\text {nd }}$ ed. Southern Illinois University Press, Illinois.

Naumann, R. B.; Vital, B. R.; Carneiro, A. C. O.; Della Lúcia, R. M.; Castro Silva, J. de.; Carvalho, A. M. M. L.; Colli, A. 2008. Propriedades de chapas fabricadas com partículas de madeira de Eucalyptus urophylla S. T. Blake e de Schizolobium amazonicum Herb. Revista Árvore 32: 11431150 .

Okino, E. Y. A.; Andahur, J. P. V.; Santana, M. A. E.; Souza, M. R. 1997. Resistência físicomecânica de chapas aglomeradas de bagaço de cana-de-açúcar modificado quimicamente. Scientia Forestalis 52: 34-42.

Papadopoulos, A. N.; Hill, C. A. S.; Gkavareli, A.; Ntalos, G. A.; Karastergiou, S. P. 2004. Bamboo chips (Bambusa vulgaris) as an alternative lignocellulosic raw material for particleboard manufacture. Holz als Roh- und Werkstoff 62: 36-39.

Ross, R.J.; Pellerin, R.F. 1988. NDE of wood-based composites with longitudinal stress waves. Forest Products Journal 38 (5): 39-45.

Souza, F.; Del Menezzi, C. H. S.; Bortoletto, Jr.G. 2010. Material properties and nondestructive evaluation of laminated veneer lumber (LVL) made from Pinus oocarpa and P. kesiya. In Press European Journal of Wood and Wood Products (DOI: 10.1007/s00107-010-0415-0)

Targa, L. A.; Ballarin, M. A.; Biaggioni, M. A. M. 2005. Avaliação do módulo de elasticidade da madeira com uso de método não-destrutivo de vibração transversal. Engenharia Agricola 25: 291299.

Teixeira, D. E.; Garlet, A.; Sanches, K. L. 2009. Resistance of particleboard panels made of agricultural residues and bonded with synthetic resins or PVC plastic to wood-rotting fungi. Cerne 15: 413-420.

Teixeira, D. E.; Moslemi, A. 2001. Assessing modulus of elasticity of wood-fiber cement (WFC) sheets using nondestructive evaluation (NDE). Bioresource Technology 79: 193-198.

Vital, B.R.; Lehmann, W. F.; Boone, R. F. 1974. How species and board densities affect properties of exotic hardwood particleboards. Forest Products Journal 24 (12): 37-45. 